\title{
A novel hybrid promoter responsive to pathophysiological and pharmacological regulation
}

\author{
Maria C. Subang $\cdot$ Rewas Fatah $\cdot$ Carly Bright $•$ Patricia Blanco • \\ Mariana Berenstein • Ying Wu • Osvaldo L. Podhajcer • Paul G. Winyard • \\ Yuti Chernajovsky • David Gould
}

Received: 7 July 2011 /Revised: 30 September 2011 /Accepted: 13 October 2011 /Published online: 30 October 2011

(C) The Author(s) 2011. This article is published with open access at Springerlink.com

\begin{abstract}
The aim of this study was to construct a promoter containing DNA motifs for an endogenous transcription factor associated with inflammation along with motifs for pharmacological regulation factors. We demonstrate in transfected cells that expression of a gene of interest is induced by hypoxic conditions or through pharmacological induction, and also show pharmacological repression. In vivo studies utilised electroporation of plasmid to mouse paws, a delivery method shown to be effective by bioluminescence imaging. For gene therapy, the promoter was used to drive expression of IL-1Ra in a paw inflammation model with therapeutic effect observed which was further enhanced when the promoter was additionally induced with a pharmacological activator. One of the most important observations from this study was that promoter induction by hypoxia or inflammation could be prevented by the pharmacological repressor in the absence of doxycycline. These studies demonstrate that hybrid
\end{abstract}

M. C. Subang $\cdot$ R. Fatah $\cdot$ C. Bright $\cdot$ Y. Wu $\cdot$ Y. Chernajovsky $\cdot$

D. Gould $(\bowtie)$

Bone and Joint Research Unit, Barts and The London School

of Medicine and Dentistry, William Harvey Research Institute,

Queen Mary University of London,

Charterhouse Square,

London EC1M 6BQ, UK

e-mail: d.j.gould@qmul.ac.uk

P. Blanco $\cdot$ M. Berenstein $\cdot$ O. L. Podhajcer

Fundacion Instituto Leloir,

Av. Patricias Argentinas 435,

Buenos Aires, Argentina

P. G. Winyard

Institute of Biomedical and Clinical Science,

Peninsula Medical School, University of Exeter,

St Luke's Campus,

Exeter, UK promoters enable pharmacological adjustment to the pathophysiological level of gene expression and, importantly, that they allow termination of gene expression even in the presence of pathophysiological stimuli.

Keywords Gene therapy - Regulated gene expression . Hypoxia $\cdot$ Tetracycline $\cdot$ Inflammation $\cdot$ Arthritis

\section{Introduction}

Gene therapy has started to prove effective in the treatment of monogenic diseases through both ex vivo and in vivo modification of cells [1,2]. With our increasing confidence in the effectiveness and safety of gene therapy, it has the potential to be utilised for the treatment of polygenic diseases where existing biological treatments could be delivered by improved strategies and in a more costeffective manner. One of the major advantages of gene therapy is the potential for local treatment of disease. By delivering vectors or engineered cells at disease sites, therapeutic proteins can be produced at their site of action, thus minimising systemic side effects. Strategies for local treatment could be further optimised by harnessing changes in the disease process to directly control the gene therapy. This could be achieved by harnessing changes in transcription factor activation associated with the disease to drive expression of a therapeutic molecule [3]. This type of gene expression system is being examined in several disease models including inflammation and cancer [4-9]. These expression systems have the potential to link expression levels of therapeutic molecules to the level of disease activity which would be particularly useful in conditions where there are periods of remission and relapse such as multiple sclerosis and rheumatoid arthritis (RA). A poten- 
tial disadvantage of this approach could be insufficient expression of therapeutic molecules or dysregulated or inappropriate expression in response to a second pathology. An alternative would be to combine a disease responsive expression system with a pharmacologically regulated system so that expression from a disease responsive component could be switched 'off' or enhanced through pharmacological control.

Hypoxic responsive gene regulation systems are dependent on the fact that under normoxic conditions, the transcription factor hypoxia-inducible factor- 1 alpha $(\mathrm{HIF}-1 \alpha)$ is rapidly degraded by the proteasome pathway [10]. Under hypoxic conditions, HIF- $1 \alpha$ is stabilised and forms a heterodimeric transcription factor with the constitutively expressed HIF-1 $\beta$, which is able to bind to a DNA motif (RCGTG) known as the hypoxia response element (HRE) located in the enhancer region of several genes including vascular endothelial growth factor and erythropoietin. Several studies have shown that repeats of the HRE can be positioned upstream of a minimal promoter element and selectively induce gene expression in response to hypoxic stimulation [11-14].

Gene expression can also be regulated using a variety of synthetic systems that are responsive to pharmacological induction [15]. The tetracycline system has the advantage of being responsive to antibiotics that have defined pharmacokinetics and are known to be safe for in vivo use. The tetracycline system [16] has undergone considerable development for gene therapy application. Pharmacological regulation would enable the physician to regulate gene expression in response to clinical symptoms of a disease.

Others have shown that the tetracycline operon remains functional when incorporated into a tissue-specific promoter [17], so we thought it would be feasible to combine disease-regulated and pharmacologically regulated gene expression systems in a single unit that could be utilised in a gene therapy application. The disease process would induce gene expression from the system. In the event that expression levels were too low, therapeutic levels could be achieved through additional pharmacological promoter induction. Alternatively, if expression levels were too high, or adverse effects were observed, expression could be reduced or shut down through pharmacological repression.

Here, we design and construct a hybrid promoter system that responds to physiological and pharmacological regulation with these characteristics.

\section{Materials and methods}

DNA and cells

Plasmid DNA was propagated in $\mathrm{DH} 5 \alpha$ and $\mathrm{DH} 21$ Escherichia coli and was purified using the Qiagen Endo-
Free Mega Kit (Qiagen Ltd., Crawley, West Sussex, UK). Standard vectors used in this study include pGL3-basic and pRL-CMV (Promega Corp., Madison, WI, USA) and pcDNA3 (Invitrogen, Leek, The Netherlands). The vectors pUHDrtTA2 ${ }^{\mathrm{S}}$-M2 [18] encoding rtTA2 $^{\mathrm{S}}$-M2 and pCMVtet $\mathrm{R}(\mathrm{B} / \mathrm{E})-\mathrm{KRAB}[19]$ encoding tetR-KRAB were gifts from Prof. W. Hillen (Institute for Microbiology, Erlangen, Germany). The plasmids pcLuc + [20], pGsmCMV, pGtL [21] and pMIK (encoding both $\mathrm{rtTA}_{2}{ }^{\mathrm{S}}-\mathrm{M} 2$ and tetR(B/E)KRAB from a constitutive promoter) [22] have been previously described. Cell lines used were a human fibrosarcoma cell line HT 1080 (ECACC ref no. $85111505)$ and the human embryonic kidney epithelial cell line 293T. Cells were routinely cultured in DMEM (BioWhittaker, Wokingham, UK) supplemented with penicillin $(100 \mathrm{U} / \mathrm{ml})($ BioWhittaker), streptomycin $(100 \mu \mathrm{g} / \mathrm{ml})$ (BioWhittaker), glutamine (2 mM) (BioWhittaker) and 10\% foetal bovine serum (GibcoBRL, Paisley, UK).

\section{Cloning}

A 39-bp smCMV promoter equivalent to -52 to -14 of the wild-type promoter [23] was cloned into pGL3-Basic forming the vector pGL3smCMV. The HRE derived from the human VEGF gene was constructed by annealing sense 5' TCGAGACACAGTGCATACGTGGGTTTCCA CAGGTCGTCTCACTCCCCGCCAG 3' and antisense 5' TCGACT GGCGGGGA GT GA GA C GA C C T G T G GAAACCCACGTATGCACTGTGTC 3' oligonucleotides (Invitrogen) containing a 5' Xho I site and a $3^{\prime}$ Sal I site (HRE motif in bold). Four repeats of the HRE were first cloned into the vector pGL3smCMV restricted with Xho I generating the plasmid pH-Luc. The hybrid promoter $\mathrm{P}_{\mathrm{TH}}$ containing tet $\mathrm{O}$ and HRE repeats was constructed by removing the four repeats of the HRE by restriction with Sma I and Hind III and inserting them into pGtL restricted with Stu I and Hind III forming the construct pTH-Luc. The $\mathrm{P}_{\mathrm{TH}}$ promoter has transcriptionally responsive elements in a compact arrangement, with the tet $\mathrm{O}$ repeats located adjacent to elements responsive to hypoxia by a distance of 74 nucleotides.

Human IL-1Ra was removed from the retroviral vector MFG-IRAP (gift from P.D. Robbins, University of Pittsburgh, USA) and cloned into pcDNA3 digested Bam HI-Xho I creating the plasmid pcIL-1Ra. Then, IL-1Ra was removed from pcIL-1Ra with Hind III and Xba I and cloned into pH-Luc restricted with Hind III-Xba I, to give the vector pH-IL-1Ra. IL-1Ra was also cloned into the hybrid promoter vector pTH-Luc, restricted Hind III-Eco RV to remove luciferase and generate the construct pTH-IL-Ra.

Promoter constructs were confirmed by DNA sequencing (Advanced Biotechnology Centre, London, UK) and/or restriction digests. Vectors are depicted schematically in Fig. 1. 
Plasmid

pcLuct

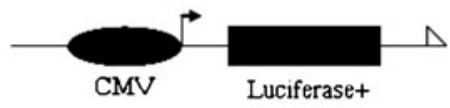

PCIL-1Ra

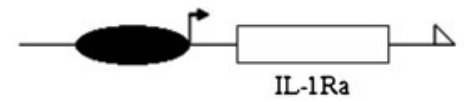

IL-1Ra

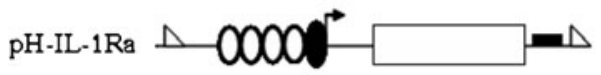

$\mathrm{P}_{\mathrm{H}}$

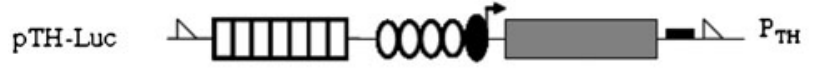

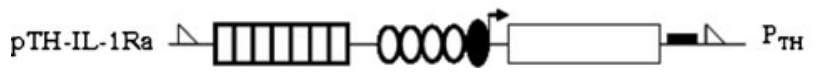

Fig. 1 Schematic representation of expression constructs generated and utilised in this study. Expressed genes are firefly luciferase targeted to peroxisomes (grey rectangle) or cytoplasm (black rectangle) and IL-1Ra (white rectangle). Promoter and response elements included the wildtype and the small minimal CMV promoters (large and small black ovals, respectively), the tet $\mathrm{O}$ (small white rectangles) and the HRE (white ovals). Polyadenylation signals are indicated by a small triangle and a $3^{\prime}$ untranslated region as a small black rectangle

\section{Transient transfection}

Transient transfections were performed using the calcium phosphate precipitation method previously described [24]. Cells were plated on 12-well plates at a density of 1 to $5.0 \times$ $10^{5}$ cells per well. After overnight culture, cells were transfected with 1 to $5 \mu \mathrm{g}$ of DNA. In experiments measuring firefly luciferase, the vector pRL-CMV encoding Renilla luciferase was also included as a control for transfection efficiency and cells were stimulated $24 \mathrm{~h}$ after transfection.

Pathophysiological and pharmacological gene induction in vitro

Induction of luciferase gene expression was performed by incubation of cells with hypoxia ( $0.1 \%$ oxygen) in a Galaxy R $\mathrm{CO}_{2}$ incubator (RS Biotech, Irvine, Ayrshire, Scotland). Experiments monitoring expression of IL-1Ra at different $\mathrm{O}_{2}$ concentrations were performed by collecting media from cells after incubation at each $\mathrm{O}_{2}$ concentration before adding fresh media and then placing the cells in the next oxygen concentration. Incubation time at each oxygen concentration was between 6 and $16 \mathrm{~h}$, and expressed IL-1Ra was calculated per hour at each $\mathrm{O}_{2}$ concentration. Expression under the control of the tetracycline inducible 'on' system utilised doxycycline (Dox) (Sigma-Aldrich Co. Ltd, Dorset, UK).

\section{IL-1Ra ELISA}

The human IL-1Ra ELISA utilised an antibody pair from R\&D systems (Minneapolis, MN, USA; MAB280 at a concentration of $4 \mu \mathrm{g} / \mathrm{ml}$ and BAF280 at a concentration of $200 \mathrm{ng} / \mathrm{ml}$ ). A standard ELISA protocol was used, and absorbance measurements were performed at $450 \mathrm{~nm}$ using a Tecan Genios microplate reader (Tecan Group Ltd, Männedorf, Switzerland) with Magellan 4 software. The detection limit of this ELISA was 10-100 pg/ml human IL-1Ra.

\section{Dual luciferase assay}

The dual luciferase assays was obtained from Promega (Promega Corp.), and the assay was performed according to the manufacturer's protocol with minor modifications. Light emission was measured using an MLX Microtiter ${ }^{\circledR}$ Plate Luminometer (Dynex Technologies Inc., Chantilly, Virginia, USA).

In vivo delivery of plasmid to mouse paws

Mice were treated according to approved Home Office and Institutional guidelines. Mice were treated with the muscle relaxant Hypnorm ${ }^{\mathrm{TM}}$ (Janssen Animal Health, Jansen Pharmaceuticals, Belgium) by i.p. injection and then anaesthetised with halothane (Concord Pharmaceuticals Ltd, Essex, UK) or AErrane (isofluorane, Baxter Healthcare Ltd, Thetford, Norfolk) using Boyle's apparatus (British Oxygen Company, London, UK). Plasmid DNA $(20 \mu \mathrm{g})$ prepared in $50 \mu \mathrm{l}$ saline was delivered by intraplantar (i.pl.) injection. Electroconducting ultrasound gel (Henleys Medical, Welwyn Garden, Herts, UK) was then applied to upper and lower surfaces of the paw before electroporation $(200 \mathrm{~V} / \mathrm{cm} / 20 \mathrm{~ms} / 2 \mathrm{~Hz} / 4$ pulses repeated four times with reversal of polarity) was performed using a BTX Electro Square Porator ECM 830 (BTX Instrument Division Harvard Apparatus Inc. Holliston, MA) and caliper electrodes 384L (Harvard Apparatus Inc.).

\section{Non-invasive bioluminescent imaging}

Imaging was performed as previously described [25]. When mice were repeatedly imaged, the same image settings were used on each occasion. Images were captured and analysed using Living Image ${ }^{\circledR}$ software v2.5.50.1 (Caliper Life Sciences Corp., Hopkinton, MA, USA).

Antigen-induced paw inflammation

Male BALB/c mice ( 9 weeks old) were treated with Hypnorm $^{\mathrm{TM}}$ or were anaesthetized with isofluorane and were then immunized with methylated bovine serum albumin (mBSA) $(100 \mu \mathrm{g})$ (Sigma-Aldrich Company Ltd.) emulsified with complete Freund's adjuvant and injected i.d. at the tail base. Eight or 12 days later, groups of four to five mice were 
injected with plasmid $(20$ or $100 \mu \mathrm{g})$ in both paws by the procedure described above. On day 14, baseline paw thickness was measured using POCO $2 \mathrm{~T}$ calipers (Kroplin Längenmesstechnik, Schlüchtern, Germany) and some mice were imaged using the IVIS 100 system (Caliper Life Sciences Corp.). Then, mBSA (50 $\mu$ g in $50 \mu \mathrm{l}$ saline) was injected in both paws or only the left whilst $50 \mu$ l saline was injected in the right paw. Measurement of paw thickness and bioluminescent imaging were repeated on subsequent days.

Statistical methods

Significant differences were calculated using the Student's $t$ test (Microsoft Excel 97, Microsoft Corp., Redmond, WA, USA).

\section{Results}

Promoter responsiveness to hypoxic induction

In the vector $\mathrm{pH}-\mathrm{IL}-1 \mathrm{Ra}$, the human IL-Ra gene is expressed from the $\mathrm{P}_{\mathrm{H}}$ promoter composed of four HRE repeats and a minimal CMV promoter. This plasmid was used to examine the sensitivity of the $\mathrm{P}_{\mathrm{H}}$ promoter to stimulation with decreasing oxygen concentrations from $8 \%$ down to $0.1 \%$ in transiently transfected $293 \mathrm{~T}$ cells $(1 \times$ $10^{5}$ cells/well on 12-well plates). These studies showed that the $\mathrm{P}_{\mathrm{H}}$ promoter was minimally responsive to $8 \% \mathrm{O}_{2}$ but was significantly activated at $\mathrm{O}_{2}$ concentrations of $5 \%(p<$ $0.05)$ and $0.1 \%(p<0.05)$. At an $\mathrm{O}_{2}$ concentration of $0.1 \%$, the expression of IL-1Ra from the $\mathrm{P}_{\mathrm{H}}$ promoter was $1.66 \mathrm{ng} / \mathrm{h} / \mathrm{ml}$, which was $43 \%$ as active as the constitutive CMV promoter in the construct pcIL-1 Ra $(3.8 \mathrm{ng} / \mathrm{h} / \mathrm{ml})$ (Fig. 2a). We then examined the function of the $\mathrm{P}_{\mathrm{TH}}$ promoter in the vector pTH-IL-1Ra in transfected 293T cells $\left(1 \times 10^{5}\right.$ cells/well on 12 -well plates $)$ over a range of $\mathrm{O}_{2}$ concentrations and observed similar induction characteristics as the $\mathrm{P}_{\mathrm{H}}$ promoter with a threshold for activation below $8 \% \mathrm{O}_{2}$ and with maximal activation at $0.1 \% \mathrm{O}_{2}$ (Fig. 2b). When activated with $0.1 \% \mathrm{O}_{2}$, the $\mathrm{P}_{\mathrm{TH}}$ was $30 \%$ as active as the CMV promoter.

Responsiveness of the hybrid $\mathrm{P}_{\mathrm{TH}}$ promoter to physiological and pharmacological regulation

We then determined the effect of additional hybrid promoter regulation through pharmacologically responsive elements. The tetR-KRAB is a transcription repressor that binds to the tet $\mathrm{O}$ sequence in the absence of Dox, and is released from the tet $\mathrm{O}$ when Dox is present, whilst the synthetic transactivator $\mathrm{rtTA}_{2}{ }^{\mathrm{S}}-\mathrm{M} 2$ binds to the tet $\mathrm{O}$ sequence in the presence of Dox. The effect of pharmaco-
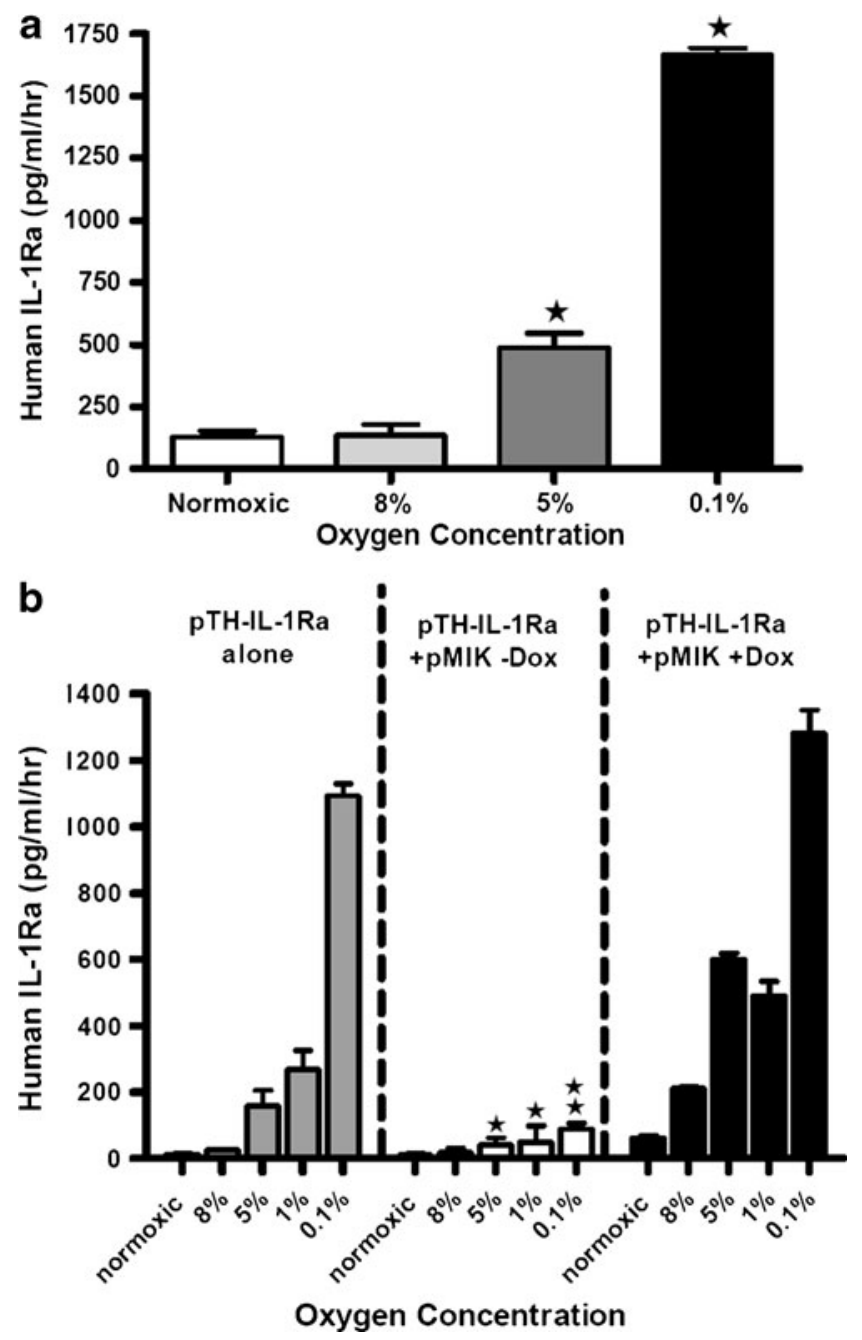

Fig. 2 Inducible gene expression from the $\mathrm{P}_{\mathrm{H}}$ and $\mathrm{P}_{\mathrm{TH}}$ promoters. The $\mathrm{P}_{\mathrm{H}}$ promoter was assessed in $293 \mathrm{~T}$ cells $(125,000$ cells/well in 12-well plates) transiently transfected with pH-IL-1Ra $(2 \mu \mathrm{g} / \mathrm{well})$ and sequentially cultured under increasingly hypoxic conditions from $8 \%$ to $0.1 \% \mathrm{O}_{2}$ (a). To assess the $\mathrm{P}_{\mathrm{TH}}$ promoter, 293T cells $\left(1 \times 10^{5}\right)$ on 12 well plates were transfected with $1 \mu \mathrm{g}$ of the plasmid pTH-IL-1Ra, alone or co-transfected with $0.1 \mu \mathrm{g}$ of pMIK. Cells were again cultured in normoxic conditions or at gradually decreasing concentrations of $\mathrm{O}_{2}$ (b). Expression levels of IL-1Ra are presented as picograms per millilitre per hour, and all values are the mean of triplicate measurements \pm SEM. A significant difference of $p \leq 0.05$ from the unstimulated and normoxic controls is indicated by a star

logical repression and activation on the hypoxic response of the $\mathrm{P}_{\mathrm{TH}}$ promoter was assessed in $293 \mathrm{~T}$ cells by cotransfection with the plasmids pTH-IL-1Ra and pMIK (that encodes both the tetracycline repressor and activator). In the absence of Dox, the $\mathrm{P}_{\mathrm{TH}}$ promoter was significantly repressed by tetR-KRAB at all $\mathrm{O}_{2}$ concentrations tested (Fig. 2b), and when cells were treated with Dox $(1 \mu \mathrm{g} / \mathrm{ml})$, additional activation of the promoter was observed at all levels of hypoxia (Fig. 2b).

In further experiments, the actions of the repressor and activator on the $\mathrm{P}_{\mathrm{TH}}$ promoter were determined in 
isolation. In these experiments, HT 1080 cells were cotransfected with the plasmid pTH-Luc encoding luciferase along with plasmid encoding tetR-KRAB or $\mathrm{rtTA}_{2}{ }^{\mathrm{S}}-\mathrm{M} 2$. We saw low $\mathrm{P}_{\mathrm{TH}}$ activity under normoxic conditions in the absence of Dox and at Dox concentrations of up to $100 \mathrm{ng} / \mathrm{ml}$ (Fig. 3a, white bars). When $\mathrm{P}_{\mathrm{TH}}$ activity was examined under hypoxia $\left(0.1 \% \mathrm{O}_{2}\right)$, we saw that tetRKRAB still repressed the $\mathrm{P}_{\mathrm{TH}}$ in the absence of Dox and the repression was gradually reversed with increasing Dox concentration (Fig. 3a, black bars). When activation by $\mathrm{rtTA}_{2}{ }^{\mathrm{S}}$-M2 was assessed under normoxic conditions, pharmacological activation was evident from a Dox concentration of $1 \mathrm{ng} / \mathrm{ml}$ and was further activated with increasing Dox concentration (Fig. 3b, white bars). When cells were stimulated with hypoxia, there was additional promoter activation at all Dox concentrations (Fig. 3b, black bars).

Plasmid delivery to mouse paws

Efficient transfection of mouse paws was achieved by i.pl. injection of plasmid DNA followed by electroporation. Using this method, luciferase expression from the plasmid pcLuc + was monitored by non-invasive bioluminescent imaging 4 days after delivery (Fig. 4a) and expression was maintained in the long term (present after 168 days, data not shown).

Function of the hybrid promoter $\mathrm{P}_{\mathrm{TH}}$ at inflammatory sites with co-expression of tetracycline regulatory molecules

The plasmids pTH-Luc and pMIK $(10 / 10 \mu g)$ were co-delivered to hind paws of mice immunized with mBSA by i.pl. injection and electroporation. Groups of four mice

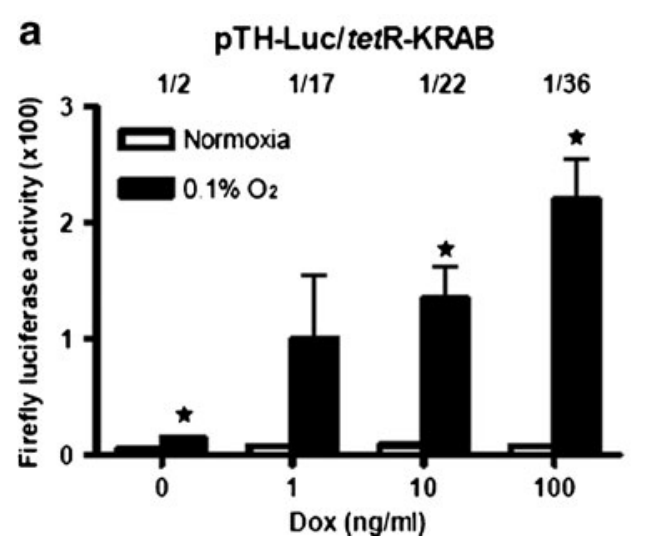

Fig. 3 Combined physiological and pharmacological regulation of hybrid promoters. The plasmid pTH-Luc $(2 \mu \mathrm{g})$ was co-transfected with plasmid encoding the tetracycline repressor-tetR-KRAB ( $2 \mu \mathrm{g}$; a)-or with plasmid encoding the tetracycline transactivatorrtTA2 ${ }^{\mathrm{S}}$-M2 $(2 \mu \mathrm{g}$; b)-along with pRL-CMV $(0.5 \mu \mathrm{g})$ in to HT1080 cells. Repression of the $\mathrm{P}_{\mathrm{TH}}$ promoter by tetR-KRAB is shown in $\mathbf{a}$, and then received either sucrose sweetened water $(10 \% w / v)$ or Dox $(20 \mu \mathrm{g} / \mathrm{ml}$ in sucrose sweetened water). On day 14 , mBSA was injected (i.pl.) into the left paw whilst saline was injected as control in the right hind paw. Changes in bioluminescence were monitored as a readout of promoter activation (Fig. 4c). In mice that received Dox, there was some basal promoter activity in both paws due to activation by $\mathrm{rtTA}_{2} \mathrm{~S}-\mathrm{M} 2$; injection of $\mathrm{mBSA}$ caused a significant induction of $\mathrm{P}_{\mathrm{TH}}$ promoter activity after $24 \mathrm{~h}$ in the inflamed paw and a smaller non-significant increase in the control paw. The higher induction in the inflamed paw is similar to the in vitro experiments where higher induction was observed with combined stimuli. In both paws, promoter activity returned below baseline by $72 \mathrm{~h}$ (Fig. 4d, e). By contrast, there was no basal or induced expression of luciferase from the $\mathrm{P}_{\mathrm{TH}}$ promoter in paws of mice that did not receive Dox (Fig. 4f, g), due to tetR-KRAB repression.

The hybrid promoter format permits pharmacological repression of disease-activated gene expression

The in vivo repression of the $\mathrm{P}_{\mathrm{TH}}$ promoter by tetR-KRAB in isolation was assessed in another experiment. The plasmids $\mathrm{pTH}-\mathrm{Luc}$ and $\mathrm{ptet} \mathrm{R}(\mathrm{B} / \mathrm{E})-\mathrm{KRAB}$ were codelivered to both paws on day 8 after mBSA immunisation. One group of mice was treated with Dox $(20 \mu \mathrm{g} / \mathrm{ml}$ in sucrose sweetened water) for 3 days prior to mBSA injection in the left paw. Prior to and after induction of inflammation, bioluminescence was monitored by real-time imaging (Fig. 5b). In mice that received Dox, there was a significant induction of luciferase expression in the inflamed left paw but not in the control paw (Fig. 5c, d). In mice that did not receive Dox, the activation of the $\mathrm{P}_{\mathrm{TH}}$

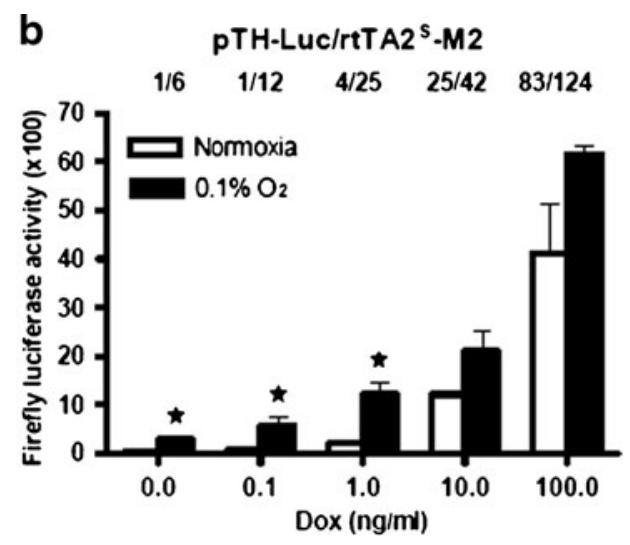

pharmacological and hypoxic induction of the $\mathrm{P}_{\mathrm{TH}}$ promoter is shown in b. Firefly luciferase values are corrected for Renilla luciferase levels, and values are the mean of triplicate measurements \pm SEM. Numbers at the top of the figures indicate the fold induction from the non-induced control. A significant induction compared to the normoxic control is indicated by a star $(p \leq 0.05)$ 


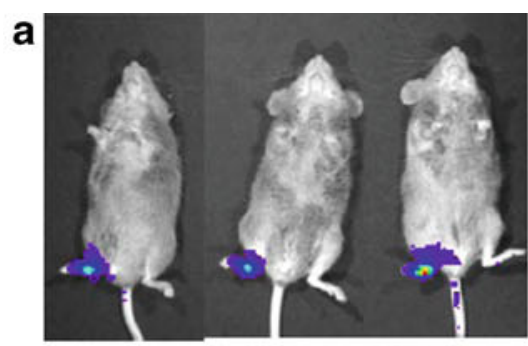

b

\begin{tabular}{|l|c|c|c|c|c|c|c|c|}
\hline PROCEDURE & Day -14 & Day -4 & Day -3 & Day -2 & Day -1 & Day 0 & Day 1 & Day 3 \\
\hline mBSA immunisation & $\checkmark$ & & & & & & & \\
Plasmid delivery & & & & & & & \\
Oral Dox or sweetened water & & $\checkmark$ & $\checkmark$ & $\checkmark$ & $\checkmark$ & $\checkmark$ & $\checkmark$ & $\checkmark$ \\
$\begin{array}{l}\text { Paws measured } \\
\text { Imaged } \\
\text { mBSA or saline injected in paws }\end{array}$ & & & & & & $\checkmark$ & $\checkmark$ & $\checkmark$ \\
\hline
\end{tabular}

C

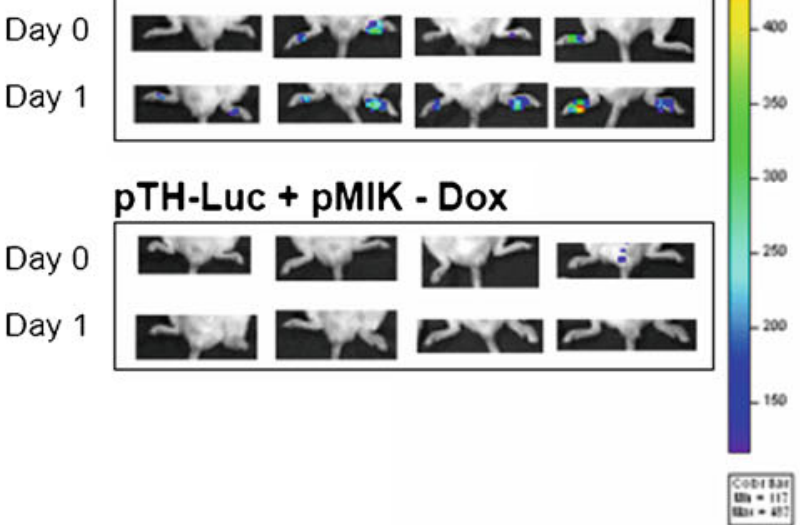

d Inflammation

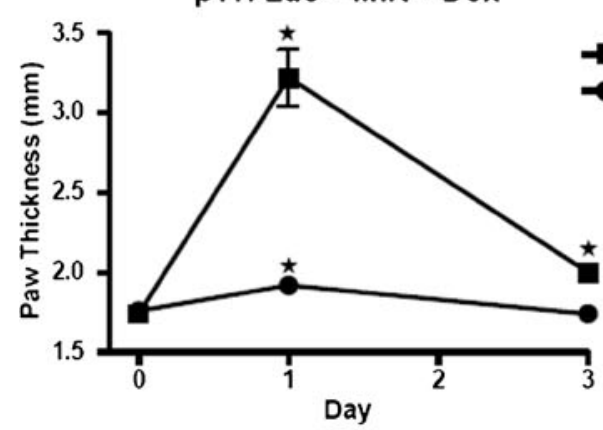

f

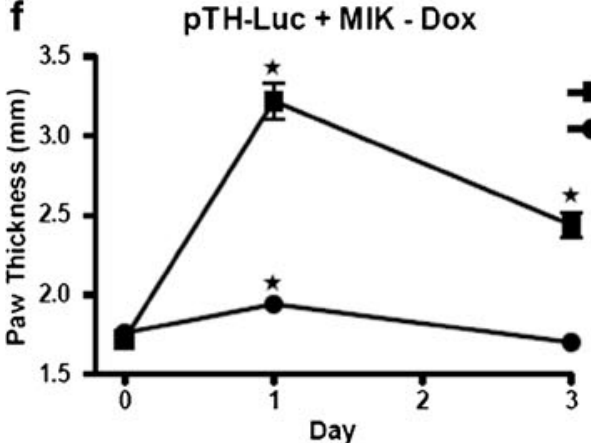

e

Bioluminescence

pTH-Luc + MIK + Dox

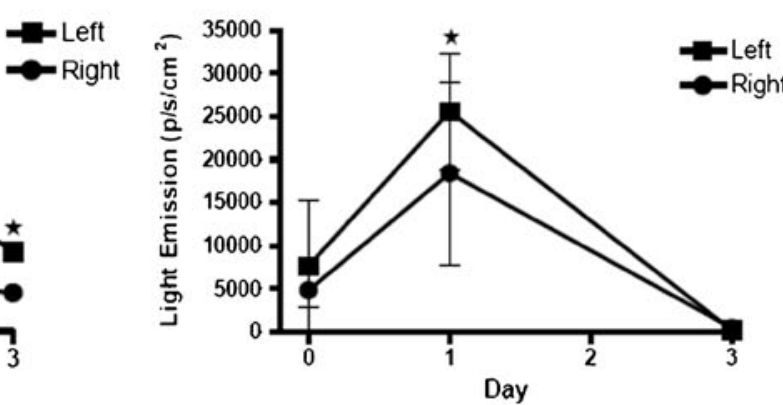

g

pTH-Luc + MIK - Dox

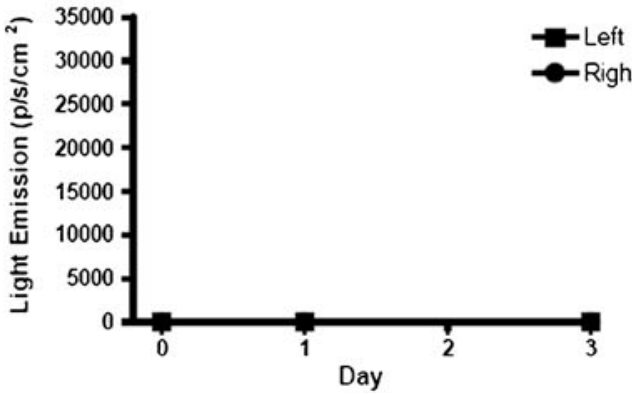


Fig. 4 Plasmid delivery to paws and $\mathrm{P}_{\mathrm{TH}}$ activity in inflammation. Plasmid DNA pcLuc $+(20 \mu \mathrm{g})$ was delivered to the right paw of three naïve DBA/1 mice by i.pl. injection followed by electroporation. Expression of luciferase was monitored by non-invasive bioluminescent imaging on day 4 (a). To assess in vivo activity of the promoter $\mathrm{P}_{\mathrm{TH}}$ an experiment was designed using bioluminescent imaging in an antigen-induced paw inflammation model according to the tabulated experimental plan (b). The plasmid pTH-Luc $(10 \mu \mathrm{g})$ containing the $\mathrm{P}_{\mathrm{TH}}$ promoter and pMIK $(10 \mu \mathrm{g})$ encoding $\mathrm{rtTA}_{2}{ }^{\mathrm{S}}-\mathrm{M} 2$ and tet $\mathrm{R}$ $\mathrm{KRAB}$ were co-delivered to both paws of four $\mathrm{BALB} / \mathrm{c}$ mice 10 days after immunisation with mBSA. A group of four mice then received Dox $(20 \mu \mathrm{g} / \mathrm{ml})$ in sucrose $(10 \% \mathrm{w} / \mathrm{v})$ sweetened drinking water whilst a second group received sweetened water alone. Inflammation was induced on day 14 in the left paw by injection of mBSA whilst saline was injected in the right paw. Sequential images of luciferase activity on day 0 and day 1 are illustrated in $\mathbf{c}$ for both groups, and mean values \pm SEM for paw thickness ( $\mathbf{d}$ and $\mathbf{f}$ ) and bioluminescence (e and g) are depicted. Significant changes from baseline values are indicated by a $\operatorname{star}(p \leq 0.05)$

promoter was repressed in the inflamed paw (Fig. 5e, f). This experiment clearly demonstrates the potential of preventing disease-induced promoter activation with the pharmacologically regulated repressor.

Therapeutic effects of IL-1Ra expressed constitutively or from the $\mathrm{P}_{\mathrm{TH}}$ promoter in the antigen-induced paw inflammation model

The same plasmid delivery approach was used to assess the therapeutic effect of plasmids encoding IL-1Ra in an antigen-induced paw inflammation model. Plasmid pcIL$1 \mathrm{Ra}(100 \mu \mathrm{g})$ constitutively expressing IL-Ra was delivered by i.pl. injection along with electroporation 12 days after mBSA immunisation. Two days later, inflammation was induced by i.pl. injection of the antigen mBSA. Increase in hind paw thickness was significantly reduced in the mice that received pcIL-1Ra compared with control mice that received the control plasmid pcDNA3 (Fig. 6a). Expression of IL-1Ra from the plasmid $\mathrm{P}_{\mathrm{TH}}-\mathrm{IL}-1 \mathrm{Ra}(100 \mu \mathrm{g})$ was also assessed in this model along with the effect of pharmacological repression and activation by co-administration of the plasmid pMIK $(10 \mu \mathrm{g})$. A significant inhibition in paw thickness was observed in mice treated with pTH-IL-1Ra alone and in those mice that received the plasmids pTHIL-1Ra+pMIK and were Dox-treated compared with animals that were treated with pTH-IL-1Ra+pMIK but were not given Dox (Fig. 6c).

\section{Discussion}

In this study, we have constructed a promoter responsive to the transcription factor HIF- $1 \alpha$ which plays a key role in inflammation [26-28] and is demonstrated in RA tissue [29]. The hypoxia-responsive promoter $\mathrm{P}_{\mathrm{H}}$ showed increasing responsiveness to decreasing $\mathrm{O}_{2}$ concentration. The promoter shows minimal activation under normoxic conditions and at $\mathrm{O}_{2}$ concentrations down to $8 \%$ which is the range of $\mathrm{O}_{2}$ tensions found in healthy tissue and the mild hypoxia found in normal joints [30]. As $\mathrm{O}_{2}$ concentration reduced from $5 \%$ to $0.1 \%$, there is a concomitant increase in promoter activity. This activity equates well to the environment of RA joints where $\mathrm{O}_{2}$ levels below $5 \mathrm{mmHg}$ (less than $1 \% \mathrm{O}_{2}$ ) have been measured which is caused by reduced oxygen supply to the joint space [31, 32], and the expression of HIF- $1 \alpha$ has also been demonstrated in a rodent model of paw inflammation [33]. In addition to stabilisation of HIF- $1 \alpha$ in response to hypoxia, it has also been shown in response to cytokines (IL-1 $\beta$ and TNF- $\alpha$ ) [34-36], reactive oxygen species [37] and hormones [38].

A disadvantage of disease responsive promoters is the lack of external control. Where promoters are responsive to inflammation, inappropriate activation may occur in response to inflammation associated with a second pathology or infection. An alternative is to combine pharmacological and pathophysiological regulation in a single system. A good example of this was reported by Payen et al. [39], where they placed the expression of the tetracycline transactivator molecule rtTA under the control of a hypoxia-regulated promoter and expressed luciferase in a second vector from a $\mathrm{P}_{t e t}$. In this arrangement, luciferase expression is co-dependent on both hypoxia and Dox. We have adopted a different strategy by directly incorporating tetracycline responsive elements and disease responsive elements in a hybrid promoter, which can be activated independently by HIF-1 $\alpha$ or pharmacologically (Dox) through the tetracycline regulatory components (rtTA2 ${ }^{\mathrm{S}}$ M2). These activation signals can be combined to give at least additive promoter induction. When targeted with the repressor tet $\mathrm{R}-\mathrm{KRAB}$, the promoter is turned 'off' in the absence of Dox, even in the presence of activators of the endogenous pathway. Importantly, in vivo experiments with the $\mathrm{P}_{\mathrm{TH}}$ promoter clearly demonstrate that in the absence of Dox, the promoter is actively repressed by tetR-KRAB, and when Dox is administered, the repression is reversed and the promoter responds to inflammation induction.

In previous gene therapy studies, systemic and local expression of IL-1Ra has inhibited inflammatory responses in several arthritis models; however, inflammation in antigen-induced arthritis is more resistant to treatment with IL-1Ra administered systemically as protein [40] and only responds when local gene therapy is performed [41]. Therefore, the significant inhibition of inflammation observed with both constitutive and regulated expression of IL-1Ra was a clear demonstration of therapeutic effect. When IL-1Ra was expressed from a regulated system, Dox was administered by injection to ensure that animals received sufficient Dox for promoter activation. The daily injection of $500 \mu \mathrm{g}$ is equivalent to the daily Dox intake 


a
\begin{tabular}{|l|c|c|c|c|c|c|c|c|}
\hline PROCEDURE & Day -14 & Day -6 & Day -3 & Day -2 & Day -1 & Day 0 & Day 1 & Day 3 \\
\hline mBSA immunisation & $\checkmark$ & & & & & & & \\
Plasmid delivery & & $\checkmark$ & & & & & & \\
Oral Dox or sweetened water & & & $\checkmark$ & $\checkmark$ & $\checkmark$ & $\checkmark$ & $\checkmark$ & $\checkmark$ \\
Paws measured & & & & & & $\checkmark$ & $\checkmark$ & $\checkmark$ \\
Imaged & & & & & $\checkmark$ & $\checkmark$ & $\checkmark$ \\
mBSA injected in paws & & & & & $\checkmark$ & & \\
\hline
\end{tabular}

b
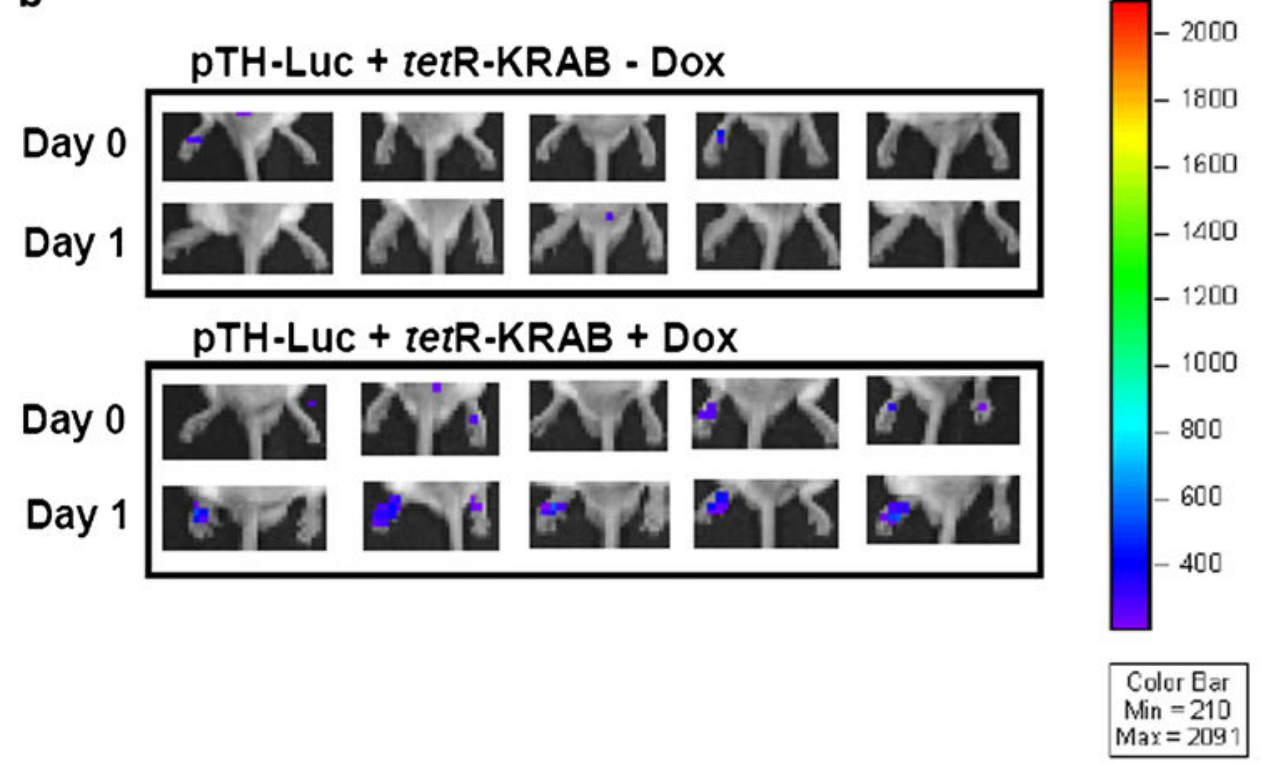

c Inflammation

pTH-Luc + tetR-KRAB + Dox/
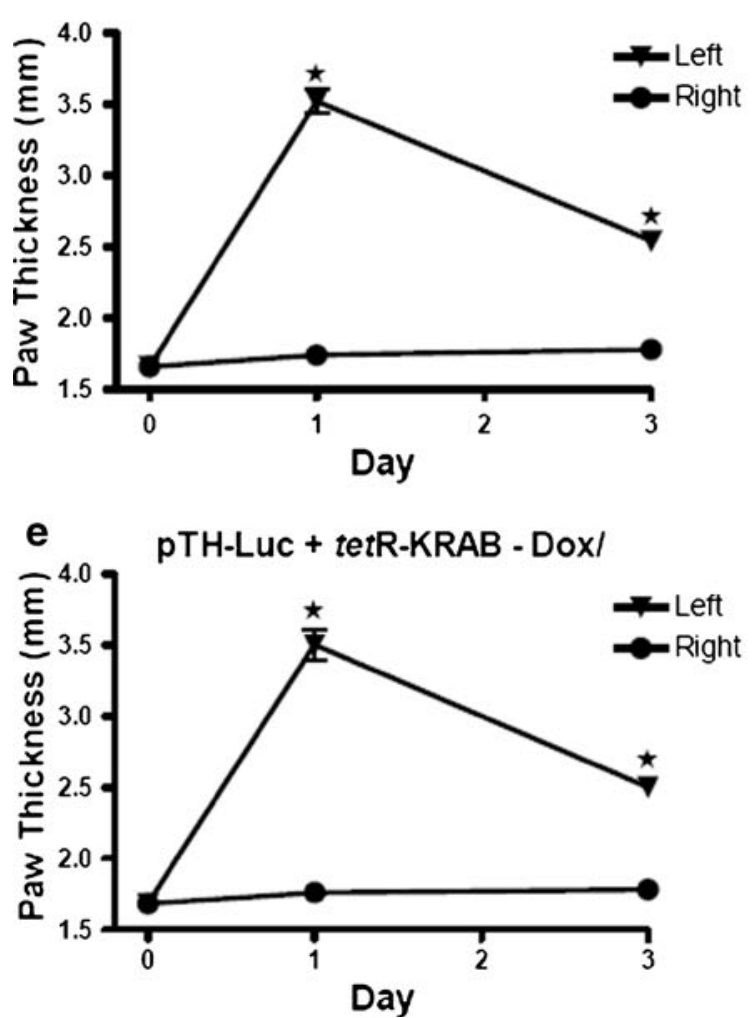

d Bioluminescence

pTH-Luc + tetR-KRAB + Dox I
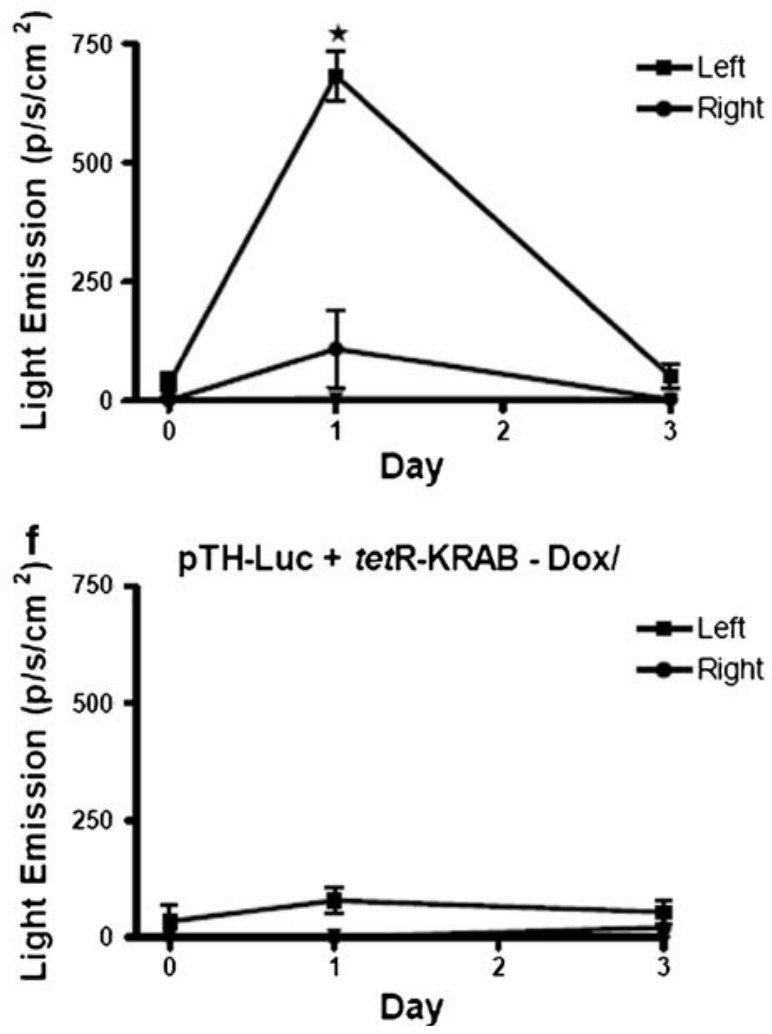
4Fig. 5 Pharmacological repression of the $P_{T H}$ promoter. In order to examine pharmacological repression of the $\mathrm{P}_{\mathrm{TH}}$ promoter by tetR-KRAB, the plasmids pTH-Luc and $\mathrm{pCMV}$-tetR(B/E)-KRAB were co-delivered to both paws of $\mathrm{BALB} / \mathrm{c}$ mice 8 days after mBSA immunisation $(n=5$ per group). Dox containing $(20 \mu \mathrm{g} / \mathrm{ml})$ sweetened drinking water was supplied to one group from day 11 and mBSA injected into the left paw of both groups on day 14. Bioluminescence was measured prior to mBSA injection (day 0) and at post-injection time points of day 1 and day 3. This experimental plan is summarized in a and sequential images obtained on days 0 and 1 for both groups are illustrated in $\mathbf{b}$, whilst changes in paw thickness (c and e) and quantified changes in bioluminescence (d and f) are also illustrated. Significant changes from baseline values are indicated by a star $(p \leq 0.05)$

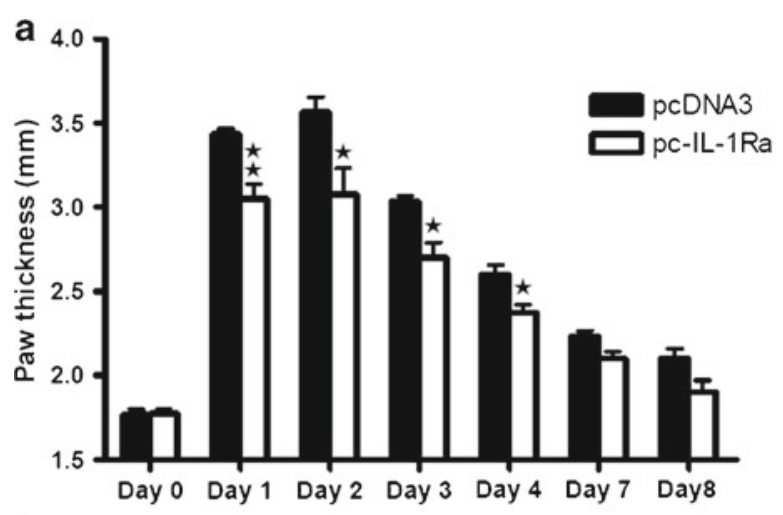

b

\begin{tabular}{|l|c|c|c|c|cc|}
\hline PROCEDURE & Day-14 & Day -2 & Day -1 & Day 0 & Day 1 to & Day 7 \\
\hline mBSA immunisation & $\checkmark$ & $\checkmark$ & & & & \\
Plasmid delivery \\
mBSA injected in both paws & & $\checkmark$ & & $\checkmark$ & & \\
Dox injected \\
Paws measured & & & $\checkmark$ & $\checkmark$ & $\checkmark$ & $\checkmark$ \\
\hline
\end{tabular}

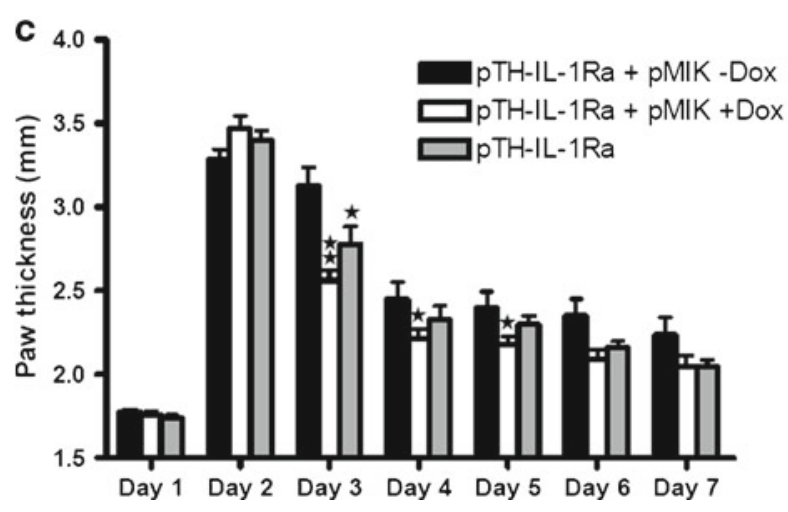

Fig. 6 Effect of constitutive and regulated IL-1Ra expression in the mouse antigen-induced paw inflammation model. a Plasmid pcDNA3 or pcIL-1Ra $(100 \mu \mathrm{g}$ in $50 \mu \mathrm{l}$ saline) were both delivered to six paws of mBSA immunized mice on day 12. mBSA was injected into paws 2 days later, and inflammation was monitored by measurement of paw thickness with calipers. The experimental plan to show gene therapy with IL-1Ra expressed from the $\mathrm{P}_{\mathrm{TH}}$ promoter is summarized in $\mathbf{b}$. Plasmid DNA $(100 \mu \mathrm{g})$ pTH-IL-1Ra, alone (grey bars) or in combination with pMIK at a ratio of 10:1, was delivered by i.pl. injection with electroporation in hind paws ( $n=8$ for each group) on day 12. On day $14, \mathrm{mBSA}$ was delivered by injection into both hind paws and Dox (500 $\mu$ g daily i.p. injection) was delivered to one pTHIL-1Ra+pMIK group (white bars) whilst the other pTH-IL-1Ra+pMIK group did not receive Dox (black bars) (c). Significant difference from the pcDNA3 group or the pTH-IL-1Ra+pMIK-Dox group are indicated by single star $(p \leq 0.05)$ and double star $(p \leq 0.01)$ that we have observed in previous gene therapy studies using the tetracycline system where Dox was supplied as a drink at a concentration of $200 \mu \mathrm{g} / \mathrm{ml}$ [20]. Inhibition of inflammation was greater in the Dox-treated group due to the fact that IL-1Ra expression was induced from the point of Dox administration (day 13) prior to $\mathrm{mBSA}$ injection. Whilst in the $\mathrm{P}_{\mathrm{TH}}$-IL-1Ra group, expression would not be induced until injection of antigen (day 14). As anticipated, the inflammation was highest in the $\mathrm{P}_{\mathrm{TH}}$-IL-1Ra+pMIK group not treated with Dox where no therapeutic gene was expressed.

The tetR-KRAB was first utilised to repress eukaryotic gene expression by Deuschle et al. [42] who incorporated tet $\mathrm{O}$ repeats into promoters such as $\mathrm{CMV}$ and were able to repress constitutive gene expression with tetR-KRAB in the absence of tetracycline. Upon addition of tetracycline, the repression was reversed. The observations in our study demonstrate pharmacological repression of physiologically regulated promoters. This ability to shut down gene expression in the absence of Dox provides a potential mechanism to stop gene expression in the event of adverse side effects which could be an important safety feature for gene therapy in non-fatal human disease. In addition, in chronic relapsing conditions such as RA, the approach could be used to prevent long-term therapeutic gene expression by restricting expression to periods of active disease.

The bioluminescent assessment of promoter activation demonstrated in this study is a useful tool because it provides a real-time indication of promoter activity. However, there are limitations of this approach as sensitivity is affected by the spatial location and depth in the tissue of the expressed luciferase protein. The light signal is reduced by photons travelling a greater distance through tissue, so inflammation, which increases tissue thickness, will compromise the detection of light and therefore lead to an underestimation in promoter activation in these studies. Notwithstanding these limitations, the bioluminescent studies have provided clear indication of promoter activation in vivo.

This study highlights the potential of expressing genes at inflammatory sites in direct response to the disease process. The ability to combine disease and pharmacological regulation in a single promoter has advantages, especially with regard to safety which will be important in any longterm gene therapy for non-fatal chronic diseases.

Acknowledgements The research was funded by Arthritis Research UK (grant numbers C0662 and 17208), The British Council, EU FP6 (Genostem: LSHB-CT-2003-503161), Wellcome Trust (grant 071329/ $\mathrm{Z} / 03 / \mathrm{Z}$ ) and Fundacion Antorchas (Argentina).

Conflict disclosure The authors declare that they have no conflict of interests. 
Open Access This article is distributed under the terms of the Creative Commons Attribution Noncommercial License which permits any noncommercial use, distribution, and reproduction in any medium, provided the original author(s) and source are credited.

\section{References}

1. Gaspar HB, Parsley KL, Howe S, King D, Gilmour KC, Sinclair J, Brouns G, Schmidt M, Von Kalle C, Barington T, Jakobsen MA, Christensen HO, Al Ghonaium A, White HN, Smith JL, Levinsky RJ, Ali RR, Kinnon C, Thrasher AJ (2004) Gene therapy of X-linked severe combined immunodeficiency by use of a pseudotyped gammaretroviral vector. Lancet 364:2181-2187

2. Cideciyan AV, Aleman TS, Boye SL, Schwartz SB, Kaushal S, Roman AJ, Pang JJ, Sumaroka A, Windsor EA, Wilson JM, Flotte TR, Fishman GA, Heon E, Stone EM, Byrne BJ, Jacobson SG, Hauswirth WW (2008) Human gene therapy for RPE65 isomerase deficiency activates the retinoid cycle of vision but with slow rod kinetics. Proc Natl Acad Sci U S A 105:15112-15117

3. Varley AW, Munford RS (1998) Physiologically responsive gene therapy. Mol Med Today 4:445-451

4. van de Loo FA, de Hooge AS, Smeets RL, Bakker AC, Bennink MB, Arntz OJ, Joosten LA, van Beuningen HM, van der Kraan PK, Varley AW, van den Berg WB (2004) An inflammationinducible adenoviral expression system for local treatment of the arthritic joint. Gene Ther 11:581-590

5. Geurts J, Arntz OJ, Bennink MB, Joosten LA, van den Berg WB, van de Loo FA (2007) Application of a disease-regulated promoter is a safer mode of local IL-4 gene therapy for arthritis. Gene Ther 14:1632-1638

6. Khoury M, Adriaansen J, Vervoordeldonk MJ, Gould D, Chernajovsky Y, Bigey P, Bloquel C, Scherman D, Tak PP, Jorgensen C, Apparailly F (2007) Inflammation-inducible antiTNF gene expression mediated by intra-articular injection of serotype 5 adeno-associated virus reduces arthritis. J Gene Med 9:596-604

7. Adriaansen J, Khoury M, de Cortie CJ, Fallaux FJ, Bigey P, Scherman D, Gould DJ, Chernajovsky Y, Apparailly F, Jorgensen C, Vervoordeldonk MJ, Tak PP (2007) Reduction of arthritis following intra-articular administration of an adeno-associated virus serotype 5 expressing a disease-inducible TNF-blocking agent. Ann Rheum Dis 66:1143-1150

8. Geurts J, Joosten LA, Takahashi N, Arntz OJ, Gluck A, Bennink MB, van den Berg WB, van de Loo FA (2009) Computational design and application of endogenous promoters for transcriptionally targeted gene therapy for rheumatoid arthritis. Mol Ther 17:1877-1887

9. Hogg RT, Garcia JA, Gerard RD (2010) Adenoviral targeting of gene expression to tumors. Cancer Gene Ther 17:375-386

10. Salceda S, Caro J (1997) Hypoxia-inducible factor 1alpha (HIFlalpha) protein is rapidly degraded by the ubiquitin-proteasome system under normoxic conditions. Its stabilization by hypoxia depends on redox-induced changes. J Biol Chem 272:2264222647

11. Shibata T, Akiyama N, Noda M, Sasai K, Hiraoka M (1998) Enhancement of gene expression under hypoxic conditions using fragments of the human vascular endothelial growth factor and the erythropoietin genes. Int $\mathrm{J}$ Radiat Oncol Biol Phys 42:913-916

12. Shibata T, Giaccia AJ, Brown JM (2000) Development of a hypoxia-responsive vector for tumor-specific gene therapy. Gene Ther 7:493-498
13. Binley K, Iqball S, Kingsman A, Kingsman S, Naylor S (1999) An adenoviral vector regulated by hypoxia for the treatment of ischaemic disease and cancer. Gene Ther 6:1721-1727

14. Post DE, Van Meir EG (2001) Generation of bidirectional hypoxia/HIF-responsive expression vectors to target gene expression to hypoxic cells. Gene Ther 8:1801-1807

15. Clackson $T$ (2000) Regulated gene expression systems. Gene Ther $7: 120-125$

16. Gossen M, Bujard H (1992) Tight control of gene expression in mammalian cells by tetracycline- responsive promoters. Proc Natl Acad Sci U S A 89:5547-5551

17. Rose SD, MacDonald RJ (1997) Integration of tetracycline regulation into a cell-specific transcriptional enhancer. J Biol Chem 272:4735-4739

18. Urlinger S, Baron U, Thellmann M, Hasan MT, Bujard H, Hillen W (2000) Exploring the sequence space for tetracycline-dependent transcriptional activators: novel mutations yield expanded range and sensitivity. Proc Natl Acad Sci U S A 97:7963-7968

19. Forster K, Helbl V, Lederer T, Urlinger S, Wittenburg N, Hillen W (1999) Tetracycline-inducible expression systems with reduced basal activity in mammalian cells. Nucleic Acids Res 27:708-710

20. Gould DJ, Bright C, Chernajovsky Y (2004) Inhibition of established collagen-induced arthritis with a tumour necrosis factor-alpha inhibitor expressed from a self-contained doxycycline regulated plasmid. Arthritis Res Ther 6:R103-R113

21. Gould DJ, Chernajovsky Y (2004) Endogenous GATA factors bind the core sequence of the tetO and influence gene regulation with the tetracycline system. Mol Ther 10:127-138

22. Yousaf N, Gould DJ, Aganna E, Hammond L, Mirakian RM, Turner MD, Hitman GA, McDermott MF, Chernajovsky Y (2005) Tumor necrosis factor receptor I from patients with tumor necrosis factor receptor-associated periodic syndrome interacts with wildtype tumor necrosis factor receptor I and induces ligandindependent NF-kappaB activation. Arthritis Rheum 52:29062916

23. Boshart M, Weber F, Jahn G, Dorsch-Hasler K, Fleckenstein B, Schaffner W (1985) A very strong enhancer is located upstream of an immediate early gene of human cytomegalovirus. Cell 41:521530

24. Gould DJ, Berenstein M, Dreja H, Ledda F, Podhajcer OL, Chernajovsky Y (2000) A novel doxycycline inducible autoregulatory plasmid which displays "on"/"off" regulation suited to gene therapy applications. Gene Ther 7:2061-2070

25. Gould DJ, Yousaf N, Fatah R, Subang MC, Chernajovsky Y (2007) Gene therapy with an improved doxycycline regulated plasmid encoding a TNFalpha inhibitor in experimental arthritis. Arthritis Res Ther 9:R7

26. Cramer T, Yamanishi Y, Clausen BE, Forster I, Pawlinski R, Mackman N, Haase VH, Jaenisch R, Corr M, Nizet V, Firestein GS, Gerber HP, Ferrara N, Johnson RS (2003) HIF-1alpha is essential for myeloid cell-mediated inflammation. Cell 112:645657

27. Melillo G (2004) HIF-1: a target for cancer, ischemia and inflammation - too good to be true? Cell Cycle 3:154-155

28. Imtiyaz HZ, Simon MC (2010) Hypoxia-inducible factors as essential regulators of inflammation. Curr Top Microbiol Immunol 345:105-120

29. Hollander AP, Corke KP, Freemont AJ, Lewis CE (2001) Expression of hypoxia-inducible factor 1alpha by macrophages in the rheumatoid synovium: implications for targeting of therapeutic genes to the inflamed joint. Arthritis Rheum $44: 1540-1544$

30. Lund-Olesen K (1970) Oxygen tension in synovial fluids. Arthritis Rheum 13:769-776

31. Mapp PI, Grootveld MC, Blake DR (1995) Hypoxia, oxidative stress and rheumatoid arthritis. Br Med Bull 51:419-436 
32. Taylor P, Miotla J, Etherington P, Winlove P, Young S, Paleolog E, Maini RN (2000) VEGF release is associated with hypoxia in inflammatory arthritis. Arthritis Rheum 43:S296

33. Peters CL, Morris CJ, Mapp PI, Blake DR, Lewis CE, Winrow VR (2004) The transcription factors hypoxiainducible factor 1alpha and Ets-1 colocalize in the hypoxic synovium of inflamed joints in adjuvant-induced arthritis. Arthritis Rheum 50:291-296

34. Thornton RD, Lane P, Borghaei RC, Pease EA, Caro J, Mochan E (2000) Interleukin 1 induces hypoxia-inducible factor 1 in human gingival and synovial fibroblasts. Biochem J 350(Pt 1):307-312

35. Haddad JJ, Land SC (2001) A non-hypoxic, ROS-sensitive pathway mediates TNF-alpha-dependent regulation of HIF-1alpha. FEBS Lett 505:269-274

36. Stasinopoulos I, O'Brien DR, Bhujwalla ZM (2009) Inflammation, but not hypoxia, mediated HIF-1alpha activation depends on COX-2. Cancer Biol Ther 8:31-35

37. Chandel NS, McClintock DS, Feliciano CE, Wood TM, Melendez JA, Rodriguez AM, Schumacker PT (2000) Reactive oxygen species generated at mitochondrial complex III stabilize hypoxiainducible factor-1alpha during hypoxia: a mechanism of $\mathrm{O} 2$ sensing. J Biol Chem 275:25130-25138
38. Gorlach A, Diebold I, Schini-Kerth VB, BerchnerPfannschmidt U, Roth U, Brandes RP, Kietzmann T, Busse R (2001) Thrombin activates the hypoxia-inducible factor-1 signaling pathway in vascular smooth muscle cells: Role of the p22(phox)-containing NADPH oxidase. Circ Res 89:4754

39. Payen E, Bettan M, Henri A, Tomkiewitcz E, Houque A, Kuzniak I, Zuber J, Scherman D, Beuzard Y (2001) Oxygen tension and a pharmacological switch in the regulation of transgene expression for gene therapy. J Gene Med 3:498-504

40. Wooley PH, Whalen JD, Chapman DL, Berger AE, Richard KA, Aspar DG, Staite ND (1993) The effect of an interleukin-1 receptor antagonist protein on type II collagen-induced arthritis and antigen-induced arthritis in mice. Arthritis Rheum 36:13051314

41. Kim SH, Lechman ER, Kim S, Nash J, Oligino TJ, Robbins PD (2002) Ex vivo gene delivery of IL-1Ra and soluble TNF receptor confers a distal synergistic therapeutic effect in antigen-induced arthritis. Mol Ther 6:591-600

42. Deuschle U, Meyer WK, Thiesen HJ (1995) Tetracyclinereversible silencing of eukaryotic promoters. Mol Cell Biol 15:1907-1914 